\title{
Online Pest Warning System - science for practice
}

\section{Platforma Sygnalizacji Agrofagów - nauka praktyce rolniczej}

\author{
Anna Tratwal*, Marcin Baran
}

\section{Summary}

All professional users in Poland should implement the principles of integrated plant protection within the framework of Community action for the sustainable use of pesticides. It involves integrated approach to the prevention and/or suppression of pest and diseases harmful to plants and maintaining the use of pesticides and other forms of intervention at the economically and ecologically justified levels, reducing and minimizing risk to human health and the environment. The national action plan to reduce the risks and impacts of pesticide use recommends promotion of general principles of integrated plant control rules. Therefore, to accomplish this goal the web based integrated pest control platform has been developed. The database summarizes current practices and scientific knowledge on plant protection, and contains the results of monitoring of most important pests in crop plants. The pest signaling platform has become a multilateral tool which supports decision making in Integrated Pest Management.

Key words: pests/diseases monitoring, integrated control, signaling, Online Pest Warning System

\section{Streszczenie}

W ramach wspólnotowego działania na rzecz zrównoważonego stosowania pestycydów, na terenie kraju, obowiązuje przestrzeganie zasad integrowanej ochrony roślin przez wszystkich profesjonalnych użytkowników. Wiąże się to z podjęciem właściwych środków mających na celu zahamowanie rozwoju populacji organizmów szkodliwych oraz utrzymanie stosowania środków ochrony roślin i innych form interwencji na ekonomicznie i ekologicznie uzasadnionym poziomie, zmniejszając lub minimalizując zagrożenia dla zdrowia ludzi oraz środowiska. Krajowy plan działania na rzecz ograniczenia ryzyka związanego ze stosowaniem środków ochrony roślin zakłada upowszechnianie ogólnych zasad integrowanej ochrony roślin. Zaistniała zatem potrzeba utworzenia platformy internetowej poświęconej integrowanej ochronie roślin. W tym celu stworzono bazę danych składającą się z kompendium wiedzy w zakresie ochrony roślin dla wszystkich użytkowników, którzy pragną poszerzyć swoją wiedzę w danym zakresie oraz wyników monitorowania najważniejszych agrofagów roślin rolniczych. Stworzona Platforma Sygnalizacji Agrofagów stała się wielostronnym narzędziem ułatwiającym oraz wspomagającym podejmowanie decyzji w integrowanej ochronie roślin.

Słowa kluczowe: monitoring agrofagów, integrowana ochrona, sygnalizacja, Platforma Sygnalizacji Agrofagów

Instytut Ochrony Roślin - Państwowy Instytut Badawczy

Zakład Monitorowania i Sygnalizacji Agrofagów

Władysława Węgorka 20, 60-318 Poznań

*corresponding author: a.tratwal@iorpib.poznan.pl 


\section{Wstęp / Introduction}

Od dnia 1 stycznia 2014 roku na mocy Dyrektywy Parlamentu Europejskiego i Rady 2009/128/WE z dnia 21 października 2009 r. ustanawiającej ramy wspólnotowego działania na rzecz zrównoważonego stosowania pestycydów, na terenie Rzeczpospolitej Polskiej, obowiązuje przestrzeganie zasad integrowanej ochrony roślin przez wszystkich profesjonalnych użytkowników. Zgodnie z definicją ,integrowana ochrona roślin" oznacza staranne rozważenie wszystkich dostępnych metod ochrony roślin, a następnie przedsięwzięcie właściwych środków mających na celu zahamowanie rozwoju populacji organizmów szkodliwych oraz utrzymanie stosowania środków ochrony roślin i innych form interwencji na ekonomicznie i ekologicznie uzasadnionym poziomie, a także zmniejszenie lub zminimalizowanie zagrożenia dla zdrowia ludzi i środowiska. Należy podkreślić, że działania i zasady integrowanej ochrony w warunkach polskiego rolnictwa nie są nowością. Producenci rolni oraz doradcy od wielu lat stosują różne metody zapobiegające skutkom zbyt dużego nasilenia występowania szkodników czy patogenów chorobotwórczych. Obowiązujące na terenie naszego kraju zasady i metody integrowanej ochrony są działaniami interdyscyplinarnymi, wymagającymi współpracy różnych specjalistów i obejmującymi swoim zakresem wiele dziedzin, takich jak entomologia, fitopatologia, uprawa roli i roślin, gleboznawstwo i inne. Integrowana ochrona roślin kładzie nacisk na uzyskanie założonych przez producenta plonów (bez pozostałości środków ochrony roślin, uszkodzeń, objawów porażenia przez agrofagi itp.) przy minimalnych zakłóceniach funkcjonowania ekosystemu rolniczego i zachęca do stosowania naturalnych sposobów zwalczania szkodników. Upowszechnienie integrowanych programów ochrony różnego rodzaju upraw na terenie kraju wymaga podjęcia działań, do których należy zaliczyć między innymi przygotowanie służb doradczych do propagowania i nadzorowania integrowanej ochrony, zmianę programów nauczania na wszystkich poziomach edukacji, a przede wszystkim zmiany sposobu ich podejścia do ochrony roślin i środowiska rolniczego (Pruszyński 2011; Matyjaszczyk 2013). Treść dyrektywy, określa zadania, jakie stawiane są profesjonalnym użytkownikom oraz instytucjom naukowym zajmującym się ochroną roślin. W dyrektywie dotyczącej integrowanej ochrony jest mowa o potrzebie systematycznego monitorowania występowania chorób i szkodników przy wykorzystaniu odpowiednich metod i narzędzi. Ponadto należy wspomagać się różnego rodzaju systemami ostrzegania i wczesnego diagnozowania opartymi na solidnych podstawach naukowych. Ponadto, przed wykonaniem zabiegu ochrony roślin, należy wziąć pod uwagę wartości progów szkodliwości dla danego regionu, konkretnego obszaru, uprawy i konkretnych warunków pogodowych. Systematyczne monitorowanie agrofagów jest bardzo ważnym elementem integrowanej ochrony. Monitorowanie dy- namiki pojawu agrofagów ma na celu rozpoznanie zagrożeń roślin uprawnych ze strony organizmów szkodliwych. Dzięki monitorowaniu występowania agrofagów roślin uprawnych możliwe jest określenie aktualnego stanu fitosanitarnego roślin uprawnych dla potrzeb prognozowania optymalnego terminu wykonania zabiegu ochronnego, czyli sygnalizacji zabiegów (Walczak 1999, 2010). Umiejętne wykorzystanie wyników obserwacji polowych pod kątem nasilenia występowania agrofagów, przyczynia się do zminimalizowania ryzyka ewentualnych szkód i wyeliminowania nadmiernego, często niepotrzebnego zużycia środków chemicznych, na co zwraca uwagę dyrektywa o integrowanej ochronie roślin. Monitorowanie umożliwia wykonanie zabiegu w optymalnym terminie, z uwzględnieniem wartości progu ekonomicznej szkodliwości.

Celem monitoringu agrofagów jest przede wszystkim zdobycie informacji o aktualnym stanie fitosanitarnym roślin uprawnych dla prawidłowej sygnalizacji zabiegów ochrony roślin.

Poza zapisami i wytycznymi zawartymi w dyrektywie o integrowanej ochronie, zalecenia związane z przestrzeganiem zasad integrowanej ochrony zapisane są również w założeniach „Krajowego Planu Działania na rzecz ograniczenia ryzyka związanego ze stosowaniem środków ochrony roślin”. W tym dokumencie, w różnych działaniach jest między innymi mowa o potrzebie upowszechniania ogólnych zasad integrowanej ochrony roślin, oraz utworzeniu i utrzymaniu platformy internetowej poświęconej integrowanej ochronie roślin. Biorąc pod uwagę wytyczne dyrektywy o integrowanej ochronie i zalecenia Krajowego Planu Działania podjęto decyzję o utworzeniu jednej strony internetowej, gdzie będzie można znaleźć jak najwięcej informacji związanych $\mathrm{z}$ integrowaną ochroną oraz informacje dotyczące stałego, systematycznego monitorowania występowania najważniejszych chorób i szkodników roślin uprawnych.

Poza tym bardzo ważnym bodźcem był fakt, że na wielu stronach różnych instytucji naukowych, naukowo-badawczych, doradczych itp., jest bardzo dużo informacji promujących stosowanie zasad integrowanej ochrony pomocnych dla rolników i doradców. Każda z tych stron ma inną konstrukcję i układ, co może przysparzać trudności $\mathrm{z}$ wykorzystaniem informacji w nich zawartych, często nieaktualnych.

\section{Materiały i metody / Materials and methods}

Instytut Ochrony Roślin - Państwowy Instytut Badawczy w Poznaniu, we współpracy z Instytutem Ogrodnictwa w Skierniewicach, Instytutem Uprawy Nawożenia i Gleboznawstwa - Państwowym Instytutem Badawczym w Puławach, w roku 2016 uruchomił portal internetowy Platforma Sygnalizacji Agrofagów (rys. 1) (http://www.agrofagi.com.pl), 
który jest istotnym elementem wspierającym realizację celów i działań związanych z przestrzeganiem wytycznych integrowanej produkcji i ochrony roślin uprawnych. Do prowadzenia Platformy Sygnalizacji Agrofagów włączyły się także wszystkie wojewódzkie ośrodki doradztwa rolniczego, Centrum Doradztwa Rolniczego w Brwinowie, Centralny Ośrodek Badania Odmian Roślin Uprawnych w Słupi Wielkiej, Instytut Hodowli i Aklimatyzacji Roślin - Państwowy Instytut Badawczy w Radzikowie oraz kilka firm prywatnych z sektora rolnego. Najważniejszą funkcją Platformy Sygnalizacji Agrofagów jest możliwość publicznego udostępniania wyników monitorowania organizmów szkodliwych w uprawach roślin rolniczych, który jest prowadzony w około 300 punktach na terenie kraju (rys. 2).

Rys. 1. Logo portalu Platforma Sygnalizacji Agrofagów

Fig. 1. Online Pest Warning System logo

\section{SPRAWDŹ ZAGROŻENIE - AGROFAG:}

\section{-- wybierz szkodnika/chorobę}

\section{Województwo:}

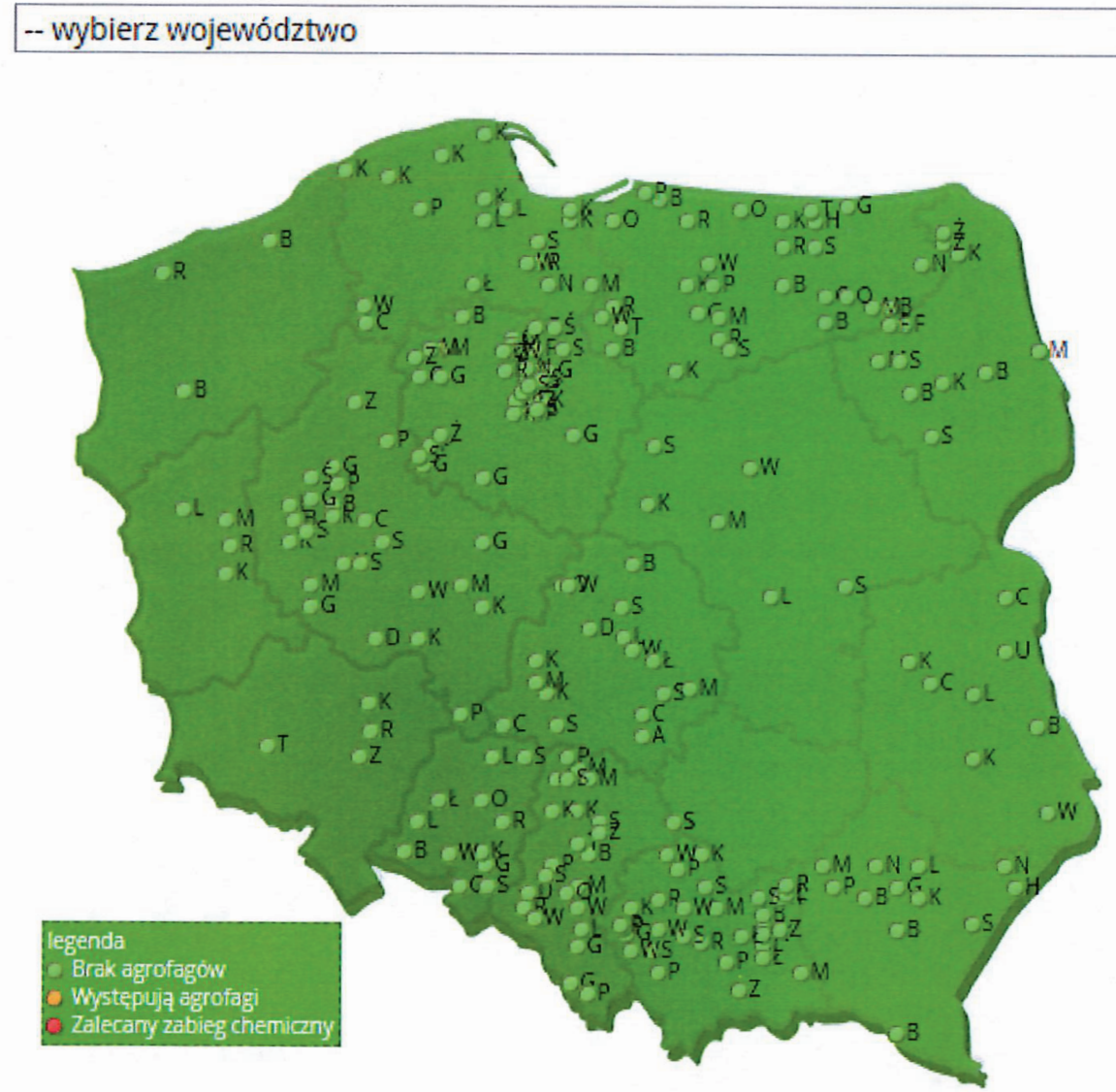

Rys. 2. Mapa kraju z punktami monitorowania organizmów szkodliwych w uprawach roślin rolniczych

Fig. 2. Map of the country with monitoring points of harmful organisms in crops of agricultural plants 
Uprawy objęte monitorowaniem to: pszenica ozima, rzepak ozimy, kukurydza, ziemniak, burak cukrowy, bobowate grubonasienne (tab. 1).

Dla wszystkich chorób i szkodników opracowane są krótkie metodyki, w których opisane są metody, terminy i narzędzia, jakie mogą być pomocne przy prowadzeniu obserwacji nad ich występowaniem. Metodyki są dostępne na Platformie Sygnalizacji Agrofagów dla każdego zainteresowanego. Główna strona internetowa składa się z sześciu modułów (rys. 3, 4).

Pierwszy to „Sygnalizacja agrofagów”, w którym udostępniane są między innymi dane z wyżej wymienionych obserwacji polowych. Opracowanie to przybliża narzędzia, które są pomocne podczas prowadzenia obserwacji, meto- dyki sygnalizacji i monitorowania agrofagów oraz systemy wspomagające podjęcie decyzji o potrzebie wykonania zabiegu chemicznego (Tratwal i Baran 2018).

Drugi moduł to „Zwalczanie agrofagów” (rys. 3), gdzie zamieszczone są opracowania, ulotki, plakaty itd. związane między innymi z ważnym zagadnieniem, jakim są Programy Ochrony Roślin. Programy (dla roślin rolniczych, sadowniczych, warzywnych, przemysłowych) mają na celu pomoc i ułatwienie producentom rolnym w dokonywaniu wyboru środków ochrony roślin przy zwalczaniu organizmów szkodliwych w uprawach metodą chemiczną. Chemiczna ochrona przed agrofagami jest wyzwaniem coraz bardziej skomplikowanym przez ciągłe zmiany w rejestrze środków ochrony roślin. Corocznie wydawanie ponad 300 zezwoleń

Tabela 1. Uprawy/agrofagi objęte monitorowaniem

Table 1. Monitored crops/pests/diseases

\begin{tabular}{|c|c|c|c|c|c|c|c|}
\hline \multicolumn{2}{|c|}{$\begin{array}{l}\text { Pszenica ozima } \\
\text { Winter wheat }\end{array}$} & \multirow{2}{*}{$\begin{array}{c}\begin{array}{c}\text { Kukurydza } \\
\text { Maize }\end{array} \\
\begin{array}{c}\text { okres } \\
\text { wiosenny/letni } \\
\text { spring/summer } \\
\text { time }\end{array}\end{array}$} & \multicolumn{2}{|c|}{$\begin{array}{l}\text { Rzepak ozimy } \\
\text { Oilseed rape }\end{array}$} & \multirow{2}{*}{$\begin{array}{c}\text { Burak } \\
\text { cukrowy } \\
\text { Sugar beet } \\
\text { okres } \\
\text { wiosenny/ } \\
\text { letni } \\
\text { spring/ } \\
\text { summer time }\end{array}$} & \multirow{2}{*}{\begin{tabular}{|c} 
Ziemniak \\
Potato \\
okres \\
wiosenny/ \\
letni \\
spring/ \\
summer time
\end{tabular}} & \multirow{2}{*}{$\begin{array}{c}\text { Łubin, } \\
\text { groch, bobik, } \\
\text { soja } \\
\text { Lupine, pea, } \\
\text { beans, soy } \\
\text { okres } \\
\text { wiosenny/ } \\
\text { letni } \\
\text { spring/ } \\
\text { summer time }\end{array}$} \\
\hline $\begin{array}{l}\text { Okres wiosenny/ } \\
\text { letni } \\
\text { Spring/summer } \\
\text { time }\end{array}$ & $\begin{array}{l}\text { okres jesienny } \\
\text { autumn time }\end{array}$ & & $\begin{array}{l}\text { okres wiosenny/ } \\
\text { letni } \\
\text { spring/summer } \\
\text { time }\end{array}$ & $\begin{array}{l}\text { okres jesienny } \\
\text { autumn time }\end{array}$ & & & \\
\hline $\begin{array}{l}\text { Mączniak } \\
\text { prawdziwy zbóż } \\
\text { Blumeria } \\
\text { graminis }\end{array}$ & \multirow{5}{*}{$\begin{array}{c}\text { mączniak } \\
\text { prawdziwy } \\
\text { zbóż } \\
\text { Blumeria } \\
\text { graminis }\end{array}$} & \multirow{5}{*}{$\begin{array}{c}\text { ploniarka } \\
\text { zbożówka } \\
\text { Oscinella frit }\end{array}$} & & \multirow{5}{*}{$\begin{array}{l}\text { sucha zgnilizna } \\
\text { kapustnych } \\
\text { Leptosphaeria } \\
\text { spp. }\end{array}$} & \multirow{5}{*}{$\begin{array}{l}\text { chwościk } \\
\text { buraka } \\
\text { Cercospora } \\
\text { beticola }\end{array}$} & \multirow{6}{*}{$\begin{array}{c}\text { zaraza } \\
\text { ziemniaka } \\
\text { Phytophthora } \\
\text { infestans }\end{array}$} & \multirow{6}{*}{$\begin{array}{c}\text { mszyce } \\
\text { Aphidoidea }\end{array}$} \\
\hline $\begin{array}{l}\text { Septoriozy } \\
\text { Septoria }\end{array}$ & & & $\begin{array}{c}\text { czerń } \\
\text { krzyżowych } \\
\text { Alternaria }\end{array}$ & & & & \\
\hline $\begin{array}{l}\text { Brunatna } \\
\text { plamistość liści } \\
\text { Pyrenophora } \\
\text { tritici-repentis }\end{array}$ & & & & & & & \\
\hline $\begin{array}{l}\text { Skrzypionki } \\
\text { Oulema spp. }\end{array}$ & & & $\begin{array}{c}\text { chowacz } \\
\text { brukwiaczek } \\
\text { Ceutorhynchus } \\
\text { napi }\end{array}$ & & & & \\
\hline $\begin{array}{l}\text { Mszyca } \\
\text { czeremchowo- } \\
\text {-zbożowa } \\
\text { Rhopalosiphum } \\
\text { padi }\end{array}$ & & & $\begin{array}{c}\text { chowacz } \\
\text { czterozębny } \\
\text { Ceutorhynchus } \\
\text { quadridens }\end{array}$ & & & & \\
\hline \multirow{3}{*}{$\begin{array}{l}\text { Mszyca zbożowa } \\
\text { Sitobion avenae }\end{array}$} & $\begin{array}{l}\text { septorioza } \\
\text { paskowana } \\
\text { Septoria } \\
\text { tritici }\end{array}$ & $\begin{array}{c}\text { omacnica } \\
\text { prosowianka } \\
\text { Ostrinia } \\
\text { nubilalis }\end{array}$ & $\begin{array}{c}\text { chowacz } \\
\text { podobnik } \\
\text { Ceutorhynchus } \\
\text { assimilis }\end{array}$ & $\begin{array}{c}\text { pchełki ziemne } \\
\text { Alticinae }\end{array}$ & $\begin{array}{c}\text { mszyca } \\
\text { trzmielinowo- } \\
\text {-burakowa } \\
\text { Aphis fabae }\end{array}$ & & \\
\hline & \multirow{2}{*}{$\begin{array}{c}\text { mszyca } \\
\text { czeremchowo- } \\
\text {-zbożowa } \\
\text { Rhopalosiphum } \\
\text { padi }\end{array}$} & \multirow{2}{*}{$\begin{array}{c}\text { stonka } \\
\text { kukurydziana } \\
\text { Diabrotica } \\
\text { virgifera }\end{array}$} & \multirow{2}{*}{$\begin{array}{l}\text { słodyszek } \\
\text { rzepakowy } \\
\text { Meligethes } \\
\text { aeneus }\end{array}$} & \multirow[t]{2}{*}{$\begin{array}{c}\text { śmietka } \\
\text { kapuściana } \\
\text { Delia radicum }\end{array}$} & $\begin{array}{l}\text { śmietka } \\
\text { ćwiklanka } \\
\text { Pegomyia } \\
\text { hyoscyami }\end{array}$ & \multirow{2}{*}{$\begin{array}{c}\text { stonka } \\
\text { ziemniaczana } \\
\text { Leptinotarsa } \\
\text { decemlineata }\end{array}$} & \multirow[t]{2}{*}{$\begin{array}{l}\text { oprzędziki } \\
\text { Sitona }\end{array}$} \\
\hline & & & & & $\begin{array}{l}\text { rolnice } \\
\text { Agrotis }\end{array}$ & & \\
\hline
\end{tabular}


Sygnalizacja agrofagów

, O. Sygnalizacja Agrofagów

> $\prod_{i}$ Monitoring Kukurydzy

- Omacnica prosowianka

CQ Metodyki sygnalizacji i monitorowania agrofagów

L Narzędzia wspomagające monitorowanie agrofagóm

1.7. Systemy wspierające podejmowanie

decyzi w ochronie roslin

(6)

Ocena Zagrożenia Agrofagiem

Zobacz wszystkie
Zwalczanie agrofagów

Programy dla integrowanej ochrony rostin

Wykaz środków ochrony roślin dla integrowanej Produkcji

tączne stosowanie agrochemikaliớw

Programy zapobiegania odporności organizmów szkodliwych

Wyszukiwarka środków ochrony roślin

Etykiety środkơw ochrony roślin

Rejestr środków ochrony roślin

Rejestr substancii podstawowych

Ulotki zzakresu ochrony roślin

$>$ Informacje dodatkowe

Zobacz wszystke

Rys. 3. Pierwsze trzy moduły głównej strony Platformy Sygnalizacji Agrofagów

Fig. 3. The first three modules of the Online Pest Warning System main page
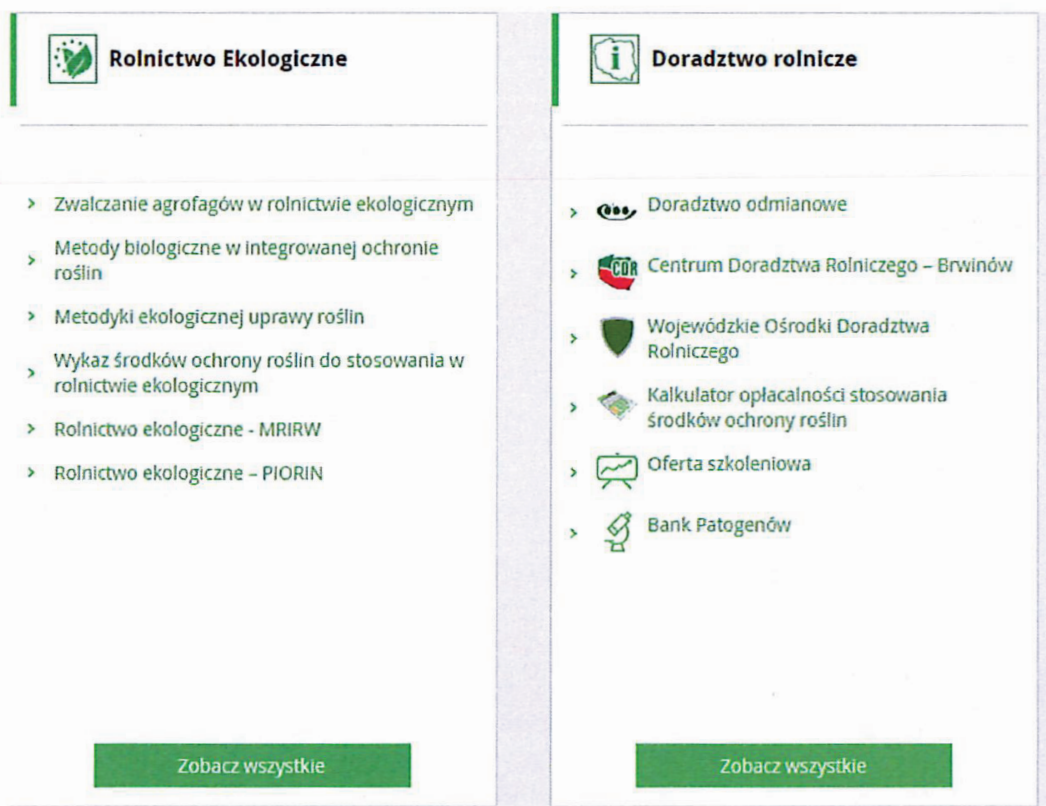

\section{Partnerzy projektu}

() Onas

(1) MRiRW

, $10 \mathrm{f} \cdot \mathrm{PIB}$

, 1 INHORT

, IUnd IUNG-PIB

(E) IHAR - PIB

Rys. 4. Kolejne trzy moduły głównej strony Platformy Sygnalizacji Agrofagów

Fig. 4. Next modules of the Online Pest Warning System main page

dla nowych preparatów oraz dokonywanie około 500 zmian w zezwoleniach wymusza bieżące korygowanie dostępnych środków chemicznych dozwolonych do stosowania. Dlatego, należy zawsze zapoznać się z bieżącym rejestrem zatwierdzonych do obrotu i stosowania substancji czynnych oraz etykietą dołączoną do środka ochrony roślin przed jego zastosowaniem. Programy zawierają również rekomendacje dotyczące użycia środków ochrony roślin w systemie
Integrowanej Produkcji Roślin (IP) oraz rolnictwie ekologicznym (EKO). Poza tym moduł ten zawiera wykaz środków ochrony roślin, ich etykiety oraz wyszukiwarki środków ochrony roślin. W tej części znajdziemy także szeroką gamę różnych ulotek związanych ze zwalczaniem agrofagów z podziałem na poszczególne grupy roślin. $\mathrm{W}$ informacjach dodatkowych można zapoznać się również z problematyką związaną z ochroną roślin zgodnie 
z wymogami państw trzecich, następstwem roślin po zaoranym rzepaku czy zbożach.

Kolejny, trzeci moduł to „Metodyki i poradniki” (rys. 3), w którym znaleźć można różnego rodzaju metodyki integrowanej produkcji i integrowanej ochrony wielu roślin uprawnych, sadowniczych, warzywnych i przemysłowych. Cennym źródłem informacji z zakresu prawidłowo wykonywanego monitorowania upraw są opracowywane i udostępniane na stronie (hppt://www.agrofagi.com.pl) „Poradniki Sygnalizatora" wielu upraw, takich jak zboża, kukurydza, bobowate drobno- i grubonasienne, uprawy warzywne, sadownicze i inne np. chmiel, tytoń czy rośliny ozdobne. W części tej znajdują się także bardzo ważne informacje, jak „Ochrona roślin bezpieczna dla zapylaczy” - wraz z plakatami i ulotkami informacyjnymi w zakresie postępowania pod kątem uniknięcia zatruć pszczół. Cennymi są również porady i opracowania z zakresu zasad bezpiecznego postępowania przy stosowaniu i przechowywaniu środków ochrony roślin oraz ich pozostałościami. Kolejnym istotnym zagadnieniem omówionym w module „Zwalczanie agrofagów” jest problem z nielegalnymi środkami ochrony roślin - „Uwaga na nielegalne środki ochrony roślin”. Środki ochrony roślin należy nabywać wyłącznie w miejscach sprzedaży uprawnionych do prowadzenia takiej działalności i nadzorowanych przez Państwową Inspekcję Ochrony Roślin i Nasiennictwa (PIORiN). Z szacunków Komisji Europejskiej wynika, że handel nielegalnymi i podrobionymi środkami ochrony roślin może obejmować blisko 10\% wartości rynku, a w proceder ten włączają się zorganizowane grupy przestępcze. W Polsce ochronę upraw można prowadzić wyłącznie z wykorzystaniem środków ochrony roślin dopuszczonych do obrotu zezwoleniem Ministra Rolnictwa i Rozwoju Wsi (rejestr lub wyszukiwarka). Zasada ta obowiązuje w każdym państwie członkowskim Unii Europejskiej, a zatem nielegalne jest również stosowanie preparatów zakupionych $\mathrm{w}$ innych państwach.

Czwarty moduł Platformy Sygnalizacji Agrofagów (rys. 4) jest poświęcony zagadnieniom związanym z rolnictwem ekologicznym. Rolnictwo ekologiczne jest najbardziej prośrodowiskową metodą produkcji rolnej, jest to obszar bardzo ważny, ale wymaga on ciągłych zmian w celu zwiększenia udziału tego sektora produkcji. Świadomość ekologiczna społeczeństwa ciągle wzrasta co wyraźnie widać przez wzrost popytu na produkty ekologiczne (Hermaniuk 2018). Na portalu zamieszczone są różnego rodzaju ulotki związane ze zwalczaniem agrofagów w rolnictwie ekologicznym. Dostępne są także linki na strony Ministerstwa Rolnictwa i Rozwoju Wsi oraz Państwowej Inspekcji Ochrony Roślin i Nasiennictwa, gdzie można zapoznać się z różnego rodzaju dokumentami, opracowaniami i rozporządzeniami prawnymi związanymi z tym zagadnieniem.

Piąty moduł, nazwany „Doradztwo rolnicze” (rys. 4), to miejsce gdzie można w dostępny sposób zlokalizować strony internetowe wszystkich Wojewódzkich Ośrodków Do- radztwa Rolniczego, Centrum Doradztwa Rolniczego, które zawierają dużo praktycznych informacji dla producentów rolnych. W tym miejscu można także zapoznać się z wynikami i zaleceniami Porejestrowego Doświadczalnictwa Odmianowego (PDO). Badania w ramach PDO ukierunkowane są na konkretne potrzeby praktyki rolniczej w dziedzinie doboru odmian do uprawy. Głównym celem badań PDO jest ułatwienie rolnikom trafnego doboru najwartościowszych odmian do uprawy, dostosowanych do lokalnych warunków. Dzięki wynikom uzyskiwanym z wielu miejscowości przez okres wielu lat zainicjowany został proces tworzenia „List Zalecanych Odmian" (LZO) do uprawy na obszarze danego województwa. Listy te zawierają od kilku do kilkunastu odmian danego gatunku rośliny uprawnej, które w trakcie, co najmniej dwuletniego okresu badań w województwie okazały się najwartościowsze i najbardziej dostosowane do lokalnych warunków gospodarowania (Gacek 1998; Gacek i Behnke 2006).

W części „Doradztwo rolnicze” (rys. 4) zawarta jest także oferta szkoleniowa dla wszystkich zainteresowanych. Szkolenia są jedną z najlepszych metod zdobycia wiedzy, uzupełnienia wykształcenia, doskonalenia umiejętności oraz podnoszenia kwalifikacji zawodowych. Wiele instytucji naukowych i doradczych, które zajmują się tematyką rolniczą, organizuje takie spotkania, zarówno dla doradców i producentów rolnych, jak i swoich pracowników. Dzięki szkoleniom możliwy jest bezpośredni transfer wyników badań naukowych do praktyki rolniczej, dotarcie z aktualnymi informacjami do odbiorców w różnych rejonach Polski, integracja środowiska osób zaangażowanych w rolnictwie, a przede wszystkim wymiana poglądów, konfrontacja doświadczeń, dyskusja między naukowcami i specjalistami a doradcami i producentami rolnymi (Hermaniuk 2018). Ma to ogromne znaczenie szczególnie dla intensywnie rozwijającego się współczesnego rolnictwa. Szkolenia, a tym samym upowszechnianie i wdrażanie do praktyki wiedzy z zakresu szeroko rozumianego rolnictwa, mają pomóc w uzyskiwaniu płodów rolnych jak najwyższej jakości.

Ostatni moduł — „O nas” (rys. 4) przedstawia opis zasad działania portalu internetowego oraz źródeł jego finansowania. Uzupełniają go loga partnerów platformy internetowej, po kliknięciu których użytkownik korzystający z portalu zostanie przekierowany na strony współtworzących Platformę Sygnalizacji Agrofagów.

\section{Podsumowanie / Conclusions}

Baza danych Platformy Sygnalizacji Agrofagów zawiera około 600 plików w formie pdf oraz około 40 przekierowań na inne strony internetowe. W latach 2017-2018 odnotowano ponad 417000 wejść na stronę http://www.agrofagi.com. pl. Świadczy to o dużej popularności strony internetowej oraz potrzebie utrzymania dynamicznie rozwijającego się 
portalu, który w przystępny i nowoczesny sposób oferuje wiedzę z dziedziny szeroko pojętej integrowanej produkcji i ochrony w rolnictwie. Monitoring agrofagów przedstawia w czasie rzeczywistym obraz zagrożeń na terenie kraju, co czyni go przydatnym narzędziem wykorzystywanym w pro- gramach i systemach ochrony roślin. Tak przystępnie udostępniona wiedza powinna być z powodzeniem wykorzystywana w praktyce rolniczej zarówno na poziomie służb doradczych, jak i indywidualnych producentów.

\section{Literatura / References}

Gacek E. 1998. Program porejestrowego doświadczalnictwa odmianowego w Polsce. Hodowla Roślin i Nasiennictwo 3: 32-34.

Gacek E., Behnke M. 2006. Wdrażanie postępu biologicznego do praktyki rolniczej w warunkach gospodarki rynkowej. Biuletyn Instytutu Hodowli i Aklimatyzacji Roślin 240/241: 83-90.

Hermaniuk T. 2018. Podstawy i zachowania konsumentów na rynku ekologicznych produktów żywnościowych. [Attitudes and consumer behaviour in the market for organic food products]. Handel Wewnetrzny 2 (373): 189-199.

Matyjaszczyk E. 2013. Plant protection in Poland on the eve of obligatory integrated pest management implementation. Pest Management Science 69 (9): 991-995. DOI: 10.1002/ps.3578.

Pruszyński S. 2011. Integrowana ochrona roślin - wyzwanie dla rolników, służb doradczych i nauki. Zagadnienia Doradztwa Rolniczego 2: 49-65.

Tratwal A., Baran M. 2018. The role of guidelines in pest monitoring and warning systems in integrated pest management. Journal of Plant Protection Research 58 (3): 211-214. DOI: 10.24425/122941.

Walczak F. 1999. Znaczenie monitoringu agrofagów roślin uprawnych dla ochrony roślin. [The role of pests and diseases monitoring for plant protection]. Progress in Plant Protection/Postępy w Ochronie Roślin 39 (1): 284-288.

Walczak F. 2010. Monitoring agrofagów dla potrzeb integrowanej ochrony roślin uprawnych. [Agrophages monitoring in agricultural integrated plant protection]. Fragmenta Agronomica 27 (4): 147-154. 